\title{
Mother Tongue-Based Multilingual Policy: Voices of Two Cities
}

\author{
Cecilia Q. Velasco \\ Laguna State Polytechnic University \\ San Pablo City Campus \\ Laguna 4000 Philippines
}

\begin{abstract}
This study was undertaken to find out he perceived efficiency and effectiveness, if such all exist, of the Mother Tongue-Based Multilingual (MTBMLE) Policy under the K-12 Curriculum as seen by the stakeholders who are directly affected by this policy. The subjects of the study were teachers from the Department of Education (DepEd) in Laguna (San Pablo City) and Ilocos Sur (Vigan City). Moreover, the parents of the two cities who are also direct stakeholders of this policy. Findings show on the comparative analysis of the two groups of teachers' perceptions on the use of mother tongue as medium of instruction, is that, there appears significant difference at all. Vigan group of teachers recognized mother tongue as an efficient and effective medium of instruction. On the other hand, both groups of parents are fully aware of the MTBMLE policy, no significant difference was found.
\end{abstract}

Keywords: effectiveness, efficiency, MTBMLE,K-12 Curriculum, DepEd

\section{Introduction}

The aim of the Department of Education in launching the K-12 curriculum is to provide a quality 12-year basic education program that each Filipino is entitled to. The purpose is not simply to add 2 more years of education "but more importantly to enhance the basic education curriculum." The change in the curriculum for basic education, though it has good intentions, brought much objections and grumblings among the stakeholders, teachers, parents and students as well. Until now, there is still a debate whether the K-12 curriculum will continue in its implementation or need to be stopped and retain the previous curriculum.

According to Cruz (2010), the implementation of the K-12 plan in the Philippine Basic Education Curriculum is the key to our nation's development. Though the government faces many problems as it implements the program over the course of several years, it is a necessary improvement since increasing the quality of our education is critical to our nation's success.

However, this far-reaching shift in the K-12 curriculum, a greater concern now on the part of the teachers and other stakeholders is the adoption of Mother-Tongue Based Education Policy, which is the use of the mother tongue as medium of instruction in the first three grade level of the pupils. In this policy, it is believed that the pupils will be competent enough in speaking, reading and writing, if mother tongue is used in the classroom. This is also to support the goal of "Every Child-A-Reader and A-Writer" by grade 1." (Article, MTB-MLE CU, 2012).

What seems more sickening in the adoption of MTBLE policy is the expected outcomes from the pupils under the $\mathrm{K}-12$ curriculum, that is, students must demonstrate the communicative competence in three languages such as Mother Tongue, Filipino and English, think intelligently, creatively and critically in life situations and others (K12 English Curriculum Guide January 2012).

Correspondingly, Ocampo, (2017), the Undersecretary for Curriculum and Instruction of the Department of Education, the K-12 program with its MTB-MLE in the Philippines aims to make all the children literate in the mother tongues by the end of Grade 1. Likewise, children should be literate in Filipino by the end of Grade 2 and all children should be literate in English by the end of Grade 3. Thus, mother tongue should be used as medium of instruction in the primary grade level of the pupils for better learning and acquisition of three languages. The researcher believes that it is right and fitting to get the views and opinions of the people directly involved and/or concerned about this education policy, the teachers of Department of Education public schools. To strengthen the validity and reliability of the study, opinions of the parents towards MTBMLE policy were also taken into consideration. This is to determine the extent of awareness on the use of mother tongue in teaching their children. 
Moreover, if results found to be positively efficient and effective medium of instruction in the language development of the pupils in the kindergarten and primary grade level, then the MTBMLE policy should be adhered by the teachers, students and its stakeholders in the quest for quality education.

\section{Review of Related Literature}

Research has shown the optimal language for literacy and learning in the primary school is the children's first language, that is, their mother tongue. Globally speaking, there are 50-75 million "marginalized" children who are not enrolled in school and/or more likely to drop out or fail in early grades because the language of instruction is not the primary language of the child (Ball, J. 2014). This indicates that children learn best when they are taught in their mother tongue right and fitting to their age group.

\subsection{Efficiency of Mother Tongue as Medium of Instruction}

Parents in countries where English is not the first language believe that their children will get a head start in education if exposed and taught in English and bypassing the home language. Kioko (2015), pointed out that many governments are now making English an official national language believing that introducing English as a medium of instruction in basic education will improve the career prospects of the young generation. However, research findings consistently show that learners benefit from using their home language in education in early grades.

In the same manner, research suggests that mother tongue as medium of instruction to the first three years of basic education is an efficient and effective medium to achieve quality learning outcomes describe what the children are expected to demonstrate in terms of knowledge, skills and values (Awopetu, 2016). Supported by Ocampo (2017), emphasized that the use of mother tongue in the primary grade level would make pupils literate in three languages; Mother Tongue, Filipino, and English by the end of grade 3.

Adesina and Okowe (2014), who studied the views on the programme of mother-tongue instruction in nursery schools in Nigeria, found out that most teachers support the programme using mother tongue as medium of instruction in nursery schools. Begi (2014), stated that the use of mother tongue as a language of instruction makes teaching and learning effective, thus efficient since it is the language that a child learns first from the mother before joining the school and the language used by majority of people in a given area or community.

John Simpson (2017), discussed the important findings that mother-tongue-based multilingual education, that young students (in a low- or middle-income countries) who are taught in their own familiar language, rather than English, understand more what they are learning and has a greater chance of be successful in the academic environment.

Correspondingly, Benson (2004) highlighted the importance of and/or efficiency of mother tongue. Learning to read is most efficient when students know the language.

\subsection{Effectiveness of Mother Tongue as Medium of Instruction}

It is the mission of every institution to support the early academic learning of the children. The Department of Education with itsnew K12 aimed to provide the children the best learning they can have by exposing them to academic skills at a progressively younger age. Children likely to drop out of school or fail in early grades if the primary language is not the language used in school. Moreover, the optimum language for literacy and learning throughout primary school is the children's first language (UNESCO,2008a; Zergani, 2016).

Since 1953, UNESCO has persuaded mother tongue as medium of instruction in primary education because they believe that children learn better in school using their mother tongue. Research also suggests that MTBMLE is a successful model in engaging the marginalized children in school (Ball, 2014; Benzon and Kosonen, 2013; Yiakoumetti, 2012).

Further, in a global context, students whose mother tongue is used as the language of instruction to their universities have an advantage over students whose mother tongue is not used as medium of instruction at their universities. This is based on the results of studies and researches that performance of students is linked to MT as medium of instruction. Results show that better and effective learning of the students in the university will be achieved if teachers have a good command of the language instruction such as international or the vernacular (mother tongue), plus the adequate knowledge of the content of the subject (Nyika, A., 2015). 
According to Kyungyah B. (2015), "a child educated in his/her original language (mother tongue) is likely more to achieve bilingualism and get better school results'. Furthermore, children perform better in their second language when learn first in their mother tongue. Likewise, teaching in a mother tongue in early school reduces dropout rates and engaging of marginalized groups in the school is noticeable (Kyungyah, 2015).

Kioko, (2015), revealed that research findings consistently show that using home language (MT) benefit the learners more in early grade years and leads to a better understanding of curriculum content and to a more positive attitude towards school.

Results and research findings were supported by Cummins (2001), emphasizing learning new languages is easier if the children have mastery of mother tongue. Children who have a solid foundation in their mother tongue, develop better literacy skills also in other languages that they learn. He then suggested that parents at home should speak their mother tongue because children are more motivated to learn new languages if parents have positive attitude towards new language learning of their children. Consequently, mother tongue is relevant and effective medium of instruction inchild's learning and overall development (Cummins, 2001).

To further discuss, a number of researches and studies all over the world have proven the dominance of mother tongue in the development and/or improvement pupils learning outcomes and/or performance. Results show that using a language familiar to the children facilitates the reading, writing and learning new concepts (Ocbian, et.al. 2015). In their study, it revealed that mother tongue based reading materials is very much acceptable to teachers. Likewise, effective medium in developing reading skills of the pupils.

Ricablanca (2014), conducted a study on the effectiveness of mother tongue based instruction on the achievement of the grade 1 pupils in mathematics. Results revealed that pupil's achievement in mother tongue-based instruction was significantly higher than the achievement of those who were in English instruction both in the posttest and retention test. This indicates that adoption of mother tongue instruction is desirable because it makes the learners learn better and easily Ricablanca, 2014).

Supported by Marnewick (n.d.), who states that, studies have found evidence to suggest that mother- tongue education leads to better academic performance of the students, likewise, it makes the acquisition of the second language easier when literacy in the home language has been achieved (Marnewick, n.d.).

Despite the debate whether mother tongue is an effective or efficient medium of instruction researchers and study results still claim that mother tongue is an effective medium of instruction to children of young age. Begi (2014),states that use of mother tongue as language of instruction makes teaching and learning effective. Moreover, learning is effective when both learners and teachers speak well the language of instruction.

\subsection{On Parent's Awareness of the k-12 Curriculum (MTBMLE Policy)}

Every school aims to give quality education to its students. Quality education does not only depend on the number of facilities and amenities that an institution or even elementary school has but it is also dependent on the teachers and most importantly, the educators in the educational system.

The quality education can be also affected by the language used by the teacher. In some countries such as Japan, and China, learning with the use of their own language is part of the curriculum. In the Philippines, where the major change in the educational landscape has been undertaken- that is the K-12 Curriculum and the use of mother tongue in basic education has become a craze in the country and the whole wide world. The Department of Education believed that using the mother tongue as medium of instruction in the kindergarten and the first three grade levels of the pupils will make learning easier and better, and of course to promote cultural heritage (Singian A. 2018).

However, no matter what changes or improvements happen in the educational system, it is important that parents of thechildren should be aware in the changes or improvements made. Parental involvement is considered an important variable in the achievement of the child's success in school. Part of the educators and/or teacher's role is to ensure that the curriculum is shared with every stakeholder in the community particularly the parents of the children (Pautler, 2018). Thus, parents should be aware and/or must be informed of the changes made in the curriculum. Olibie (2014) who studied about the extent of parental involvement and/or awareness in curriculum implementation found out that in the opinions of male and female principals, little extent of awareness and parental involvement in curriculum implementation. It was recommended that school principals and teachers should design and implement strategies that will involve parents and other stakeholders in the curriculum implementation (Olibie 2014). 
Forrest (2014), stressed in her article that national curriculum isn't neutral. Parents not politicians should be able to choose what their children are taught. Rubin (2014) emphasized that the heart of engagement for parents and students is to meaningfully involve all stakeholders on instruction and curriculum. This suggests that parents will only do their part and be involved in their child's activity if the school/educators would fully orient or inform them (parents) with the curriculum.

Hess (2017) describes the important role of the parents in the K-12 curriculum. K-12 education needs to be raised to an even par with their teachers. Parents "must do" their part to ensure their children learn. In this manner, awareness of the parents on the new curriculum (k-12) and its embedded MTBMLE policy should be comprehensively discussed to them.

Dollaga (2011) studied on the perception of the parents of the students affected by additional 2 years (K-12 Curriculum) two years in basic education revealed that implementation of k-12 program is a must because the primary objective of the program is to improve the quality of education so that the students who finished under this curriculum will be more productive according to the parent's perspective regarding k-12 program.

It can't be denied that parent's role and/or involvement in the implementation of k-12 curriculum is of great importance in the successful achievement of the goals of the program. Hence, parent's understanding of the program and the policy is essential.

\section{Objectives and Significance of the Study}

The main objective of the present study is to find out the perceived efficiency and effectiveness of the Mother Tongue-Based Multilingual (MTBMLE) Policy requiring the use of mother tongue as the sole medium of instruction for the kindergarten first three years of basic education, as seen by the teachers of the Department of Education from San Pablo and Vigan Cities. Likewise, the awareness and acceptability of MTBMLE of the corresponding parents of the students of the aforementioned cities too.

The results of this study would be of significant contribution on the adherence of K12 curriculum and its embedded MTBMLE Policy by the teachers, students and parents who are the directly affected by this sudden shift in the Basic Education Curriculum. For the teachers, designing innovative mother tongue based instructional materials will be prioritized, and using different strategies in mother tongue should be employed for better understanding of the lesson.

To students, learning will be fun and easy since majority if not all speak the language they fully understand.

To parents, support and involvement in the academic undertaking of their children through the use of mother tongue at home during conversation and helping their children with their academic work will be effortless and child's play at all.

To curriculum designers, results will give them insights to re-examine the implementation of the MTBMLE Policy and the use of mother tongue as medium of instruction and evaluate the end results of the policy.

\section{Methodology}

This study was undertaken to find out the perceived efficiency and effectiveness, if at all such exist, of the MTBMLE Policy under the K-12 Curriculum, as seen by the stakeholders who are directly affected by this policy.

The subjects of the study were teachers from the Department of Education (DepEd) schools in Laguna (San Pablo City) and Ilocos Sur (Vigan City). Moreover, the parents of the two cities who are also direct stakeholders of this policy. Researcher-made questionnaire was employed in gathering the data-- [rotated] factor analysis was used [threshold loading 0.50] to fine-tune the instrument (questionnaire). It utilized a descriptive design and quantitative analysis was used.

The first phase of the study was done in San Pablo City, Laguna, using the aforementioned instrument. The teachers from the DepEd served as first group of respondents as well as the parents of the pupils of the same schools where the respondents teach.

The second phase was conducted at Vigan City, Ilocos Sur where teachers from DepEd also served as respondents. Parents of the pupils studying from the school of the teacher-respondents were also surveyed to find out their level of awareness of MTBMLE policy where mother tongue is the medium of instruction in the class. 


\section{Results and Discussions}

\subsection{Efficiency of Mother Tongue as Medium of Instruction}

In terms of efficiency, the two groups of teachers apparently have contrasting views on the efficiency of Mother Tongue as medium of instruction. Means of 3.528 and 3.761 and mean difference of 2325 at 002 significant level indicate that the Vigan group of teachers agreed that MT is an efficient language to use in the development of pupil's speaking, reading and writing for grades 1-3 in contrast to that of San Pablo group of teachers.

\subsection{Effectiveness of Mother Tongue as Medium of Instruction}

The two groups of teachers appear to have significant difference in the perceived effectiveness of Mother Tongue as medium of instruction. Means of 3.525 and 3.671 and a mean difference of -.1459 at .042 significant level indicate that Vigan teachers somewhat agree that MT is effective medium in improving pupil's understanding of the lessons in all subject areas (except English) and ability to conceptualize ideas and views as well as learning capacity in terms of critical and creative thinking (K-12 learning competencies) while SPC group remain neutral.

\subsection{Parent's Awareness of MTBMLE Policy}

The two groups of parents who also served as respondents in the conduct of the study show that both group of parents (San Pablo City and Vigan City) are strongly aware of the policy in the K-12 Curriculum, that is, the use of Mother Tongue as medium of instruction among kindergarten and grades 1-3 pupils in the Basic Education. Means of 3.971 and 3.791 and mean difference of .1802 at .271 significant level found no significant difference between the two groups of parents.

\section{Conclusion and Recommendations}

From the perspective of the group of teachers on the use of Mother Tongue as an efficient and effective medium instruction, the Vigan group of teachers agreed that MT is an efficient and effective medium of instruction in the development of children's learning competencies under the K-12 Curriculumwhile San Pablo group of teachers remain neutral with the use of MT as medium of instruction.

It was recommended that for the teachers, designing innovative mother tongue based instructional materials should be prioritized, and using different strategies in mother tongue should be employed for better understanding of the lesson.

To parents, since they are fully aware of the MTBMLE policy is suggested to support and involve themselves in the academic undertaking of their children through the use of mother tongue at home during conversation. This is to help their children with their academic work and make learning effortless and child's play at all.

\section{Acknowledgements}

The author of this study would like to express her sincerest gratitude to the teachers from the DepEd schools of San Pablo City and Vigan City as well as parents of the two cities who served as the respondents of the study. Special thanks are given to the head and principals of the schools for the permission to conduct the study. And to the President of the University I belong, Dr. Nestor M. De Vera for the support and to my consultant Dr. Eduardo Alicias Jr, for his expertise in the analysis of the data, thank you very much.

Table 1. Perceived Efficiency of Mother Tongue as Medium of Instruction

\begin{tabular}{|c|c|c|c|c|c|c|}
\hline & \multicolumn{6}{|c|}{ Efficiency } \\
\hline $\begin{array}{c}\text { Locale of the } \\
\text { Study }\end{array}$ & $\mathrm{N}$ & Mean & $\begin{array}{c}\text { Std. } \\
\text { Deviation }\end{array}$ & $\begin{array}{c}\text { Mean } \\
\text { Difference }\end{array}$ & Tabular t & $\begin{array}{c}\text { Significance } \\
(2 \text { tailed })\end{array}$ \\
\hline San Pablo City & 248 & 3.528 & 8.255 & .2325 & -3.108 & .002 \\
\cline { 1 - 1 } & 188 & 3.761 & .6994 & & -3.179 & \\
\hline
\end{tabular}


Table 2. Perceived Effectiveness of Mother Tongue as Medium of Instruction

\begin{tabular}{|c|c|c|c|c|c|c|}
\hline & \multicolumn{6}{|c|}{ Effectiveness } \\
\hline $\begin{array}{c}\text { Locale of the } \\
\text { Study }\end{array}$ & $\mathrm{N}$ & Mean & $\begin{array}{c}\text { Std. } \\
\text { Deviation }\end{array}$ & $\begin{array}{c}\text { Mean } \\
\text { Difference }\end{array}$ & Tabular t & $\begin{array}{c}\text { Significance } \\
\text { (2 tailed) }\end{array}$ \\
\hline San Pablo City & 247 & 3.525 & .7567 & -.1459 & -2.039 & .042 \\
\cline { 1 - 1 } & 183 & 3.671 & .7030 & & -2.306 & \\
\hline Vigan City & 1806 & & \\
\hline
\end{tabular}

Table 3. Parent's Awareness on the MTBMLE Policy

\begin{tabular}{|c|c|c|c|c|c|c|}
\hline & \multicolumn{6}{|c|}{ Awareness } \\
\hline $\begin{array}{c}\text { Locale of the } \\
\text { Study }\end{array}$ & $\mathrm{N}$ & Mean & $\begin{array}{c}\text { Std. } \\
\text { Deviation }\end{array}$ & $\begin{array}{c}\text { Mean } \\
\text { Difference }\end{array}$ & Tabular t & $\begin{array}{c}\text { Significance } \\
(2 \text { tailed })\end{array}$ \\
\hline San Pablo City & 83 & 3.971 & .8238 & .1802 & 1.105 & .271 \\
\cline { 1 - 4 } & 56 & 3.791 & 1.061 & & 1.043 & \\
\hline
\end{tabular}

\section{References}

Adesina A.D. Phd, Okewoke, J.O. 2014. "Survey of Teachers Opinions on Mother-Tongue Instruction in Nigerian Nursery Schools: Implications for Educational Policy Making. International Journal of Humanities and Social Science. Volume 4, No. 10; August (2014) 247-252

Adoniou, Misty. (2014, 16 July). It's time for parents to have their say on the national curriculum. Article. The Conversation. [Online] Available: http://theconversation.com/its-time-for-parents-to-have-their-say-onthe-national-curriculum-21966 July 12, 2018.

Awopetu, Anna V. (2016, May 12-14). Impact of Mother Tongue on Children's Learning Abilities in an Early Childhood Classroom. Article. Procedia Social and Behavioral Sciences 233 (2016) 58-63.

Ball, Jessica. (2014, February 21). Children Learn Better in their Mother Tongue: Advancing Research on Mother Tongue-based Multilingual Education. Global Partnership for Education. Article February 21, 2014.

Begi, Nyakwara. (2014). Use of Mother Tongue As A Language of Instruction In Early years of School To Preserve the Kenyan Culture. Journal of Education and Practice. Volume 5, No.3 (2014) 37-49

Benson, Carole. (2004) The importance of mother tongue-based schooling for educational quality. Background paper for the Education for All Global Monitoring Report 2005. UNESCO. [Online] Available: from http://unesdoc.unesco.org/images/0014/001466/146632e.pdf June 19,2018.

Cummins, Jim (2001). Bilingual Children's Mother Tongue: Why is it important for education?[Online] Available:https://moominls.com/en/miksi-aidinkieli-on-niin-tarkeaa/ September 28, 2018.

Cruz, I. (2010, October 14). Mini Critique: The K+12 debate. The Philippine Star. [Online] Available: http://www.philstar.com/education-and-home/620399/k12-debate.Department Order No. 31 Series of 2012, Policy Guidelines on the Implementation of Grades 1 to 10 of the K-12 Basic Education Curriculum (BEC) Effective School 2012-2013 April 17, 2012

Estrada, Roselle. 2014. "The Effectiveness of Mother Tongue as Medium of Instruction in Mathematics" [Online] Available: https://prezi.com/2biigg1fvy7z/the-effectiveness-of-mother-tongue-instructions-ascurriculum/ June 18, 2018.

Forrest, Stephanie. (2014). Article. Curriculum should be decided by schools and parents, not governments. The Sydney Morning Herald. January 17, 2014.

Griffin, Jo. (2016). Why teaching them in their own language could help 500m children to stay in school and succeed. Article. [Online] Available: https://theirworld.org/news/why-teaching-in-mother-tongue-couldhelp-500m-children June 29, 2018. 
Hess, Rick. (2017). The Role of Parents in K-12 Education. [Online] Available

:http://www.thepursuitofhappiness.com/category-life/the-role-of-parents-in-k-12-education/ October 3, 2018.

Kaur, Gurmeet. (2016, April 6). Contribution of Mother Tongue in reference to the Primary Education. Retrieved from https://www.linkedin.com/pulse/contribution-mother-tongue-reference-primary-education-gurmeetkaur/ July 12, 2018

Kioko, Angelina. (2015). Why schools should teach young learners in home language. Article.British Council. [Online] Available: https://www.britishcouncil.org/voices-magazine/why-schools-should-teach-younglearners-home-language July 1,2018. K to 12 Curriculum Guide Mother Tongue (Competencies) Grades 1-3, Version as of January 31, 2012. K to 12 Curriculum Guide English Grade 1-3 and Grade 7-10. January 31,2012

Marnewick, Adrian. (n.d.). The Debate About Mother-Tongue Education: What You Should Know. [Online] Available: https://www.worksheetcloud.com/blog/the-debate-abo ut-mother-tongue-education-what-youshould-know/ September 29, 2018.

Nyika Aceme 9 Mother tongue as the medium of instruction at developing countryuniversities in a global context. S Afr J Sci. 2015;111(1/2), Art. \#2014-0005, 5 pages. http://dx.doi.org/10.17159/ sajs.2015/20140005

Ocampo, Dina S. (2017, 2 March). Mother Tongue-Based Multilingual Education (MTB-MLE) in the Philippines. [Online] Available: from

https://au.eventscloud.com/file_uploads/806b6ab12b0ebe095fa59e1d66b0cadf_Dina_ForARNECwthdinasrevisio ns02-03-2017finalfromkeynote.pdf June19, 2018.

Olibie, EyiucheIfeoma. (2014). Parental Involvement in Curriculum Implementation as Perceived by Nigeria Secondary School Principals. Journal of Education and Learning. Volume 3, No 1. (2014) 40-51.

Ocbian, Magdalena, Suod, Mary Anne, Garduque, Jhonson Jr., and Bringino, Leny F. (2015). Acceptability of Big Books as Mother Tongue-based Reading Materials in Bulusan Dialect. Asia Pacific Journal of Multidisciplinary Research, Volume 3, No.4 November (2015 Part IV) 17-23

Pautler, Rachel (2018). Eight Questions Parents Have About Your Curriculum. [Online] Available: https://www.chalk.com/resources/8-questions-parents-have-about-your-curriculum/

Ricablanca, Jovem (2014). Effectiveness of Mother Tongue-based Instruction Pupil's

Achievement in Mathematics. [Online] Available: http://www.academia.edu/10401349/EFFECTIVENESS_OF_MOTHER_TONGUEBASED_INSTRUCTIONON_PUPILS_ACHIEVEMENT_IN_MATHEMATICS September 28, 2018.

Rubin, Emma Sokoloff (2014). Chalkbeat Roundtable: Should parents have a say in curriculum? [Online] Available: https://chalkbeat.org/posts/ny/2014/04/15/chalkbeat-roundtable-should-parents-have-a-say-incurriculum-2/

Simpson, John. (2017). English language and medium of instruction in basic education in low- and middleincome countries: A British Council Perspective. [Online] Available: https://englishagenda.britishcouncil.org/sites/default/files/attachments/pub_h106_elt_position_paper_on_ english_in_basic_education_in_low-_and_middle-income_countries_final_web_v3.pdf September 11, 2018.

Singian, Annabelle. (2018). Mother Tongue and the Basic Education in the Philippines.

Article.[Online] Available: https://www.pressreader.com/philippines/sunstar-pampanga/20180322/281612420938312 September 28, 2018.

Zergani, Moein. (2016, 2 September). Effects of using and teaching with mother tongue language in primary school. [Online] Available: https://www.linkedin.com/pulse/effects-using-teaching-mother-tonguelanguage-primary-moein-zergani September 2, 2016.

R.A. 10533 An Act Enhancing the Philippine Basic Education System by Strengthening its Curriculum and Increasing the Number of Years for Basic Education, Appropriating Funds 